\title{
Plasma osmolality and protein intake in preterm infants
}

\author{
D. P. DAVIES \\ From the Department of Child Health, Welsh National School of Medicine, University Hospital of Wales, Cardiff
}

\begin{abstract}
Davies, D. P. (1973). Archives of Disease in Childhood, 48, 575. Plasma osmolality and protein intake in preterm infants. Plasma osmolality was measured in 53 preterm, low birthweight infants on 3 days (days 7, 14, and 28) during the first month of life. The aim of the study was to compare the plasma osmolality of infants fed expressed human breast milk with that of infants fed two proprietary cow's milk formulae of higher protein content.

The mean plasma osmolality in 15 infants fed Ostermilk No. 1 (group B), with protein contributing $15.4 \%$ of the total calorie intake $(2.7 \mathrm{~g} / 100 \mathrm{ml})$, did not differ from that of 17 infants on human milk (group A) in which protein made up only $5.9 \%$ of the total calorie content $(1 \cdot 1 \mathrm{~g} / 100 \mathrm{ml}$ ). 21 infants fed Ostermilk C.20 (group C), with $21 \cdot 1 \%$ of the calorie content provided by protein $(3 \cdot 7 \mathrm{~g} / 100 \mathrm{ml})$, had significantly higher mean values than group $A$ infants; the highest mean plasma osmolality occurred with a daily protein intake of $8.5 \mathrm{~g} / \mathrm{kg}$. The number of individual observations $>300 \mathrm{mOsm} / 1$. in groups $\mathrm{A}, \mathrm{B}$, and $\mathrm{C}$ were 4,4 , and 16 , accounting respectively for $9 \cdot 1,10 \cdot 8$, and $32 \cdot 6 \%$ of the total number of observations in each group. The higher plasma osmolality in group $\mathrm{C}$ infants was not accompanied by significant weight gain or clinical oedema. It is suggested that a milk formula with protein contributing more than $20 \%$ of the total calorie intake or a daily protein intake greater than $8.0 \mathrm{~g} / \mathrm{kg}$ considerably stresses the capacity of the immature kidney to maintain plasma osmolality within normal limits, and should, therefore, be used with caution if hyperosmolar states are to be avoided.
\end{abstract}

The osmolality of a solution depends on the number of dissolved particles, and in the case of plasma it refers under healthy conditions to the concentration of the ionized salts of sodium and potassium and the blood urea, with the blood glucose, plasma proteins, and other large molecules also making a contribution (Dormandy, 1967). Mechanisms which are necessary for the homoeostasis of plasma osmolality require very precise regulation if the internal environment is to remain constant, and it is therefore not surprising that, as this constancy is essential for survival, plasma osmolality is among the most jealously guarded of the body's chemical properties (Rapoport, 1947).

In the preterm infant its control might be expected to be put to a severe test during the neonatal period since renal concentrating and diluting mechanisms, which are essential for osmolality homoeostasis (Dormandy, 1967), are poorly developed (McCance, Naylor, and

Received 28 December 1972.
Widdowson, 1954; Edelmann and Barnett, 1960). Also, the immature glomerulus provides only a limited sodium and urea clearance (Gordon, Harrison, and McNamara, 1942; Edelmann and Spitzer, 1969), and this is likely to embarrass the regulatory processes even further. However, the infant is in an anabolic phase of growth at this stage of development (Sinclair et al., 1970) so that substances which would otherwise be presented to the kidney for excretion are instead incorporated into the body's developing form. In this way disturbances to the equilibrium of plasma osmolality are reduced to a minimum, with the low solute load of human milk also providing additional protection. Should the preterm infant, however, be provided with a dietary protein intake which is higher than that of human milk, then this situation might be expected to considerably stress the controlling mechanisms because the kidney will be presented with a potentially high solute load for excretion at a particularly vulnerable period.

In this investigation the stress to the immature kidney of increased dietary solute loads has been 
TABLE I

Protein and major electrolyte composition of three milk formulae per $100 \mathrm{ml}$

\begin{tabular}{|c|c|c|c|}
\hline \multirow[b]{2}{*}{ Constituent } & \multicolumn{3}{|c|}{ Milk formula } \\
\hline & $\begin{array}{c}\text { Breast milk } \dagger \\
\text { A }\end{array}$ & $\underset{\text { B }}{\text { Ostermilk No. } 1 \ddagger}$ & $\underset{\text { C }}{\text { Ostermilk C.20 }}$ \\
\hline $\begin{array}{l}\text { Protein (g) } \\
\text { Sodium (mEq) } \\
\text { Potassium (mEq) } \\
\text { Chloride (mEq) } \\
\text { Calcium (mg) } \\
\text { Inorganic phosphorus (mg) } \\
\text { Calorie content } \\
\text { Calories provided by protein (\%) } \\
\text { Renal solute load (mOsm) }\end{array}$ & $\begin{array}{c}1 \cdot 1 \\
0 \cdot 7 \\
1 \cdot 3 \\
1 \cdot 1 \\
34 \cdot 0 \\
14 \cdot 0 \\
75 \\
5 \cdot 9 \\
7 \cdot 5\end{array}$ & $\begin{array}{c}2 \cdot 7 \\
1 \cdot 8 \\
3 \cdot 4 \\
2 \cdot 4 \\
94 \cdot 0 \\
74 \cdot 0 \\
70 \\
15 \cdot 4 \\
18 \cdot 4\end{array}$ & $\begin{array}{c}3 \cdot 7 \\
2 \cdot 4 \\
4 \cdot 5 \\
3 \cdot 1 \\
95 \cdot 0 \\
75 \cdot 0 \\
70 \\
21 \cdot 1 \\
24 \cdot 8\end{array}$ \\
\hline
\end{tabular}

^Estimated renal solute load $=4$ (g dietary protein $)+(\mathrm{K}+\mathrm{Na}+\mathrm{Cl}) \mathrm{mEq}$, from Ziegler and Fomon (1971).

tTaken from Macy and Kelly (1961).

$\ddagger$ Manufacturer's data.

studied by comparing the plasma osmolality in a group of low birthweight, preterm infants fed human milk with two other similar infant groups fed higher protein milk formulae. This study forms part of a comprehensive investigation (to be published) of the role of protein in the growth and development of the low birthweight infant.

\section{Clinical material}

Study design and distribution of infants. Preterm infants weighing less than $2.5 \mathrm{~kg}$ who were admitted to the Cardiff Maternity Hospital Special Care Baby Unit were considered eligible for the study. Those not included in the final analysis were (a) infants with major congenital malformations, (b) infants with Rhesus disease (c) infants with the idiopathic respiratory distress syndrome of sufficient severity to justify parenteral feeding for more than $\mathbf{4 8}$ hours, and (d) infants who died during the first week of life.

Data from 53 preterm infants were collected for this study. Each infant had been randomly allocated on admission to one of the following three milk formulae. Formula A: expressed human breast milk, Formula B: medium protein, modified cow's milk formula (Ostermilk No. 1), and Formula $C$ : high protein, modified cow's milk formula (Ostermilk C.20).
The detailed composition of these milk formulae is given in Table I, and the distribution of the infants among the three groups together with details of birthweight, gestational age, and growth status at birth are illustrated in Table II. All these infants remained in hospital for a minimum of 7 days and at discharge they were provided with their particular milk until they were 28 days old, when they were seen at follow-up clinic. Only 3 infants remained in hospital at this time.

Measurement of plasma osmolality. Plasma osmolality was measured on three study days-day 7 and day 28 for each infant and day 14 for those still in hospital at the time. Capillary blood samples were collected by heel prick between midday and 4 p.m., with the interval between sampling and the subsequent feed being about 30 minutes. The specimens were centrifuged immediately, the plasma was separated and the osmolality measured by freezing point depression on the Knauer Semi-Micro Osmometer within 1 hour of sampling. All the values for plasma osmolality in this study are the average of duplicate observations.

Amount and technique of feeding. Beginning with $65 \mathrm{ml} / \mathrm{kg}$ of body weight on the first day, the milk formulae were fed in increasing amounts until a daily intake of $200 \mathrm{ml} / \mathrm{kg}$ was reached, usually on about the

TABLE II

Distribution of birthweight, gestation, and growth status at birth among three feeding groups of infants studied

\begin{tabular}{|c|c|c|c|c|c|c|c|}
\hline \multirow{2}{*}{ Group } & \multirow{2}{*}{ No. } & \multicolumn{2}{|c|}{$\begin{array}{l}\text { Birthweight } \\
(\mathrm{kg})\end{array}$} & \multicolumn{2}{|c|}{$\begin{array}{c}\text { Gestational age } \\
\text { (wk) }\end{array}$} & \multicolumn{2}{|c|}{$\begin{array}{l}\text { Growth status } \\
\text { at birth }\end{array}$} \\
\hline & & Mean & Range & Mean & Range & $\begin{array}{l}\text { Appropriately } \\
\text { grown for dates }\end{array}$ & Small-for-dates $\dagger$ \\
\hline $\begin{array}{l}\text { A } \\
\mathbf{B} \\
\mathbf{C}\end{array}$ & $\begin{array}{l}17 \\
15 \\
21\end{array}$ & $\begin{array}{l}2 \cdot 09 \\
2 \cdot 03 \\
1 \cdot 90\end{array}$ & $\begin{array}{l}(1 \cdot 60-2 \cdot 45) \\
(1 \cdot 51-2 \cdot 44) \\
(1 \cdot 65-2 \cdot 15)\end{array}$ & $\begin{array}{l}34 \cdot 8 \\
33 \cdot 8 \\
34 \cdot 7\end{array}$ & $\begin{array}{l}(32-36) \\
(29-36) \\
(29-36)\end{array}$ & $\begin{array}{l}14 \\
13 \\
16\end{array}$ & $\begin{array}{l}3 \\
2 \\
5\end{array}$ \\
\hline
\end{tabular}

* Standards used are those of Lubchenco et al. (1963).

tBirthweight $<10$ th centile for gestational age. 
TABLE III

Mean daily protein, water, and calorie intake per kg body weight on day 7 and day 14 in three infant groups

\begin{tabular}{|c|c|c|c|c|c|c|}
\hline \multirow{3}{*}{ Dietary constituent } & \multicolumn{2}{|c|}{ Group A } & \multicolumn{2}{|c|}{ Group B } & \multicolumn{2}{|c|}{ Group C } \\
\hline & \multicolumn{2}{|c|}{ Day } & \multicolumn{2}{|c|}{ Day } & \multicolumn{2}{|c|}{ Day } \\
\hline & 7 & 14 & 7 & 14 & 7 & 14 \\
\hline $\begin{array}{l}\text { Protein (g) } \\
\text { Water (ml) } \\
\text { Calories }\end{array}$ & a. $\begin{aligned} 2 \cdot 1 \\
191 \\
143\end{aligned}$ & $\begin{array}{r}\text { b. } 2 \cdot 6 \\
250 \\
187\end{array}$ & $\begin{array}{l}4 \cdot 6 \\
172 \\
120\end{array}$ & $\begin{array}{l}6 \cdot 7 \\
248 \\
173\end{array}$ & $\begin{array}{l}6 \cdot 8 \\
182 \\
127\end{array}$ & $\begin{array}{l}8 \cdot 5 \\
231 \\
162\end{array}$ \\
\hline
\end{tabular}

tenth day. Thereafter, volumes given were adjusted so that the infants were fed the maximum amount possible in accordance with their tolerance. Feedings were given every 3 hours, though hourly and 2-hourly feedings were frequently necessary for the small infants. Careful record was kept of the volumes of milk ingested so that the daily intake of water, protein, and calories could be accurately determined on 2 study days, day 7 and day 14 (Table III). The daily intake for day 28 was not documented as only 3 infants remained in hospital at this time, and it was unlikely to provide a true representation of the whole study group.

Clinical observations. The infants were examined regularly by one observer (D.P.D.) and careful note was taken of independent observations made by the nursing staff. Particular attention was given to the following aspects of clinical behaviour.

Weight gain. The infants were weighed on admission, twice weekly until they were discharged, and again at their first clinic appointment. The daily rate of weight gain was determined for the first 28 days of life.

Peripheral oedema. Careful inspection of the eyes, legs, and dorsum of the feet was made for the development of oedema.

\section{Results}

Mean plasma osmolality. Table IV summarizes the results. There was a similar pattern on each study day, with the mean plasma osmolality of group B not differing significantly

\section{TABLE IV}

Plasma osmolality on three study days (mean values $\pm S E)$

\begin{tabular}{c|c|c|c}
\hline \multirow{2}{*}{ Group } & Day 7 & Day 14 & Day 28 \\
\cline { 2 - 4 } A & $290 \cdot 8(1 \cdot 78)$ & $287 \cdot 2(1 \cdot 85)$ & $289 \cdot 7(1 \cdot 89)$ \\
& no. $=17$ & no. $=10$ & no. $=17$ \\
B & $289 \cdot 6(1 \cdot 79) \star$ & $291 \cdot 7(3 \cdot 24) \star$ & $293 \cdot 6(1 \cdot 03) \star$ \\
C & no. $=15$ & no. $=7$ & no. $=15$ \\
& $296 \cdot 8(1 \cdot 67) t$ & $298 \cdot 8(1 \cdot 03) \ddagger$ & $296 \cdot 7(1 \cdot 0) \S$ \\
& no. $=21$ & no. $=7$ & no. $=21$
\end{tabular}

When compared with Group $A:{ }^{\star}$ not significant $(P>0.05)$; $+P<0.05 ; \ddagger P<0.001 ; \$ P<0.01$. from group $\mathrm{A}$, but that of group $\mathrm{C}$ being significantly higher than group $\mathrm{A}$ on all three days.

Individual values $>300 \mathrm{mOsm} / \mathbf{1}$. (Table V). Since a plasma osmolality of $300 \mathrm{mOsm} / \mathrm{l}$. is regarded as the upper limit of normal (Rapoport, 1947), it was considered worth while determining the total number of individual observations above and including this value. In both groups $A$ and $B$

\section{TABLE V}

Plasma osmolality: individual values $>300 \mathrm{mOsm} / \mathrm{l}$.

\begin{tabular}{c|c|c}
\hline Group & No. & Total observations (\%) \\
\hline A & 4 & $9 \cdot 1$ \\
B & 4 & $10 \cdot 8^{\star}$ \\
C & 16 & $32 \cdot 6 \dagger$
\end{tabular}

When compared with Group A: ${ }^{\star}$ not significant $(P>0.05)$; $+P<0.01$.

there were only 4 such individual observations which accounted respectively for $9.1 \%$ and $10.8 \%$ of the total number of observations in each group. In group $\mathrm{C}$, however, there were 16 observations, $32.6 \%$ of the total number, and this was a highly significant proportion $(P<0.01)$ when compared with group $\mathrm{A}$.

Weight gain and peripheral oedema. The daily rate of weight gain during the first 28 days of life is given in Table VI. The difference which

TABLE VI

Daily rate of weight gain during first 28 days of postnatal life

\begin{tabular}{c|l}
\hline Group & $\begin{array}{l}\text { Weight }(\mathrm{g} / \mathrm{dy}) \\
(\text { Mean } \pm \text { SE) }\end{array}$ \\
\hline A & $23 \cdot 2(1 \cdot 68)$ \\
B & $23 \cdot 3(2 \cdot 05)^{\star}$ \\
C & $27 \cdot 4(1 \cdot 30)^{\star}$
\end{tabular}

$\star$ When compared with Group $A$ : not significant $(P>0.05)$. 
existed between group $\mathrm{C}$ and group $\mathrm{A}$ did not reach a level of statistical significance. Some pitting oedema of the dorsum of the feet was observed in 5 infants during the second week: 1 in group B and 2 each in groups $A$ and $C$. Since these infants were fairly evenly distributed among the three groups, it is considered unlikely that this peripheral oedema is of much clinical significance.

\section{Discussion}

It has been argued (Gordon, Levine, and McNamara, 1947) that human milk is not the food of choice for infants of low birthweight, its low protein content being unable to support an adequate growth rate in the neonatal period. Controversy, however, still exists concerning the most advantageous intake of protein for these infants (Snyderman et al., 1969). A diet which is low in protein might interfere with brain development at a particularly critical and vulnerable period (Winick, 1969; Chase, Dorsey, and McKhann, 1967). Furthermore, low birthweight infants fed low protein milk formulae providing a daily protein intake of 3.0 to $3.6 \mathrm{~g} / \mathrm{kg}(10 \%$ of the total calorie intake) have been observed to develop oedema and low plasma protein levels (Goldman et al., 1969). Higher intakes of milk protein have, on the other hand, resulted in a rise in levels of most of the amino acids (Snyderman et al., 1968; Valman et al., 1971) and blood urea (Davidson et al., 1967). Milks with protein contributing $20 \%$ of the total calorie intake $(6 \cdot 0-7 \cdot 2 \mathrm{~g} / \mathrm{kg}$ per day) have also been held responsible for hyperpyrexia and symptoms of lethargy and poor feeding (Goldman et al., 1969). Less consideration, however, seems to have been given to the effects of increased renal solute load which is caused by high protein formulae: this aspect merits study since the increased nitrogenous end-products of metabolism and the increased intake of salts, which invariably accompany higher protein intakes (Fomon, 1967), makes overloading the kidney of the premature infant a real possibility.
This study has illustrated the importance of this concept and has also shown the use of plasma osmolality as a measure of the ability of the immature kidney to cope with increases in solute load resulting from different protein intakes. Formula B (Ostermilk No. 1) with protein contributing $15.4 \%$ of total calorie intake could readily be managed, since the mean plasma osmolality did not differ significantly from that of the infants fed human breast milk, with only $5.9 \%$ protein in the total calorie content. Formula C (Ostermilk C.20), with protein contributing $21.1 \%$ of the calorie intake and providing a potential renal solute load more than 3 times that of human milk (Table I) seemed, however, to stress the capacity of the kidney to maintain plasma osmolality within normal limits since the mean plasma osmolality on all 3 study days was significantly higher in these infants compared with infants fed human milk. Also, the percentage of individual observations greater than $300 \mathrm{mOsm} / 1$. in this group constituted $32.6 \%$ of the total number, and this was highly significant when compared with $9 \cdot 1 \%$ and $10 \cdot 8 \%$ in group $A$ and $B$, respectively. In terms of actual dietary protein intake, this is likely to be between 8 and $9 \mathrm{~g} / \mathrm{kg}$ body weight since the maximum mean plasma osmolality $(298 \cdot 8)$ occurred on day 14 with an intake of $8 \cdot 5$ $\mathrm{g} / \mathrm{kg}$ (Table VII).

Kagan and co-workers (1955) showed a rapid gain in weight in infants on high protein milk formulae. They attributed this to fluid retention consequent upon the increased mineral intake which accompanied the high protein feed. In this study the raised mean plasma osmolality in the infant group fed the highest protein milk formula might also have been expected to be associated with some obligatory fluid retention since it reflects an inability of the kidney to excrete completely the dietary solute load. Peripheral oedema was not, however, a clinical feature in these infants, and the rate of weight gain was not significantly greater than in the other two groups. Similar observations have also

TABLE VII

Daily protein intake ( $\mathrm{g} / \mathrm{kg}$ ) and mean plasma osmolality

\begin{tabular}{|c|c|c|c|c|c|c|c|c|c|}
\hline & \multicolumn{3}{|c|}{ Group A } & \multicolumn{3}{|c|}{ Group B } & \multicolumn{3}{|c|}{ Group C } \\
\hline & \multicolumn{3}{|c|}{ Day } & \multicolumn{3}{|c|}{ Day } & \multicolumn{3}{|c|}{ Day } \\
\hline & 7 & 14 & 28 & 7 & 14 & 28 & 7 & 14 & 28 \\
\hline $\begin{array}{l}\text { Protein intake } \\
\text { Plasma osmolality }\end{array}$ & $\begin{array}{r}2 \cdot 1 \\
290 \cdot 8\end{array}$ & $\begin{array}{r}2 \cdot 6 \\
287 \cdot 2\end{array}$ & $\begin{array}{c}\text { ND } \\
289 \cdot 7\end{array}$ & $\begin{array}{r}4 \cdot 6 \\
289 \cdot 6\end{array}$ & $\begin{array}{r}6 \cdot 7 \\
291 \cdot 7\end{array}$ & $\underset{293.6}{N D}$ & $\begin{array}{r}6 \cdot 8 \\
296 \cdot 8\end{array}$ & $\begin{array}{r}8 \cdot 5 \\
298 \cdot 8\end{array}$ & $\begin{array}{c}\text { ND } \\
296 \cdot 7\end{array}$ \\
\hline
\end{tabular}

ND, not]determined. 
been made by Omans and co-workers (1961) who found no significant difference in the rate of weight gain in preterm infants fed daily protein intakes ranging from 3 to $9 \mathrm{~g} / \mathrm{kg}$ body weight. Likewise, Snyderman et al. (1969), studying preterm infants fed protein diets contributing daily protein intakes of 2 and $9 \mathrm{~g} / \mathrm{kg}$, found that the weight gain in both groups was also similar despite the high protein diet having twice the mineral content of the low protein diet.

The exact relation between high protein-mineral diets, fluid retention, and rates of weight gain is obviously complex and has yet to be fully worked out. It appears, however, on the basis of this study that a degree of solute retention can exist without either excessive weight gain or visible oedema. Plasma osmolality in this instance appears the more sensitive monitor of renal function with respect to the management of dietary solute load.

Hyperosmolar states in infancy are known to be associated sometimes with brain damage (Macaulay and Watson, 1967). In this present study, though there were no features to suggest any cerebral disturbance in any of the infants with a plasma osmolality greater than $300 \mathrm{mOsm} / 1$., only careful neurological and psychological follow-up examination will definitely exclude permanent cerebral handicap. The importance of such follow-up studies has recently been stressed by Goldman et al. (1971). It nevertheless seems advisable that until optimum protein intake for the low birthweight infant becomes better defined, milk formula with protein of more than $20 \%$ of the total caloric intake (or daily protein intake more than $8.0 \mathrm{~g} / \mathrm{kg}$ body weight) should be given with caution to avoid potentially harmful hyperosmolar states.

I thank the following people: Professor O. P. Gray for his valuable criticism and advice; the Nursing Staff of the Special Care Unit, Cardiff Maternity Hospital, for their patience and co-operation throughout; Sister Lewarne and the staff of the Milk Bank, St. David's Hospital, Cardiff, for so efficiently organizing the collection and delivery of the human breast milk; Glaxo Laboratories, Greenford, Middlesex, for supplying the Ostermilk formulae; Miss P. Samuel and Miss J. Griffin (of Glaxo) for invaluable nutritional advice; Miss M. Abernathy for statistical help; and Miss E. Morgan, Mrs. M. Johnson, and Mrs. R. Hoffer for secretarial assistance.

\section{REFERENCES}

Chase, H. P., Dorsey, J., and McKhann, G. M. (1967). The effect of malnutrition on the synthesis of myelin lipid. Pediatrics, 40, 551.
Davidson, M., Levine, S. Z., Bauer, C. H., and Dann, M. (1967) Feeding studies in low-birth-weight infants. I. Relationships of dietary protein, fat, and electrolytes to rates of weight gain, clinical courses, and serum chemical concentrations. Fournal of Pediatrics, 70, 695.

Dormandy, T. L. (1967). Osmometry. Lancet, 1, 267.

Edelmann, C. M., Jr., and Barnett, H. L. (1960). Role of the kidney in water metabolism in young infants. Fournal of Pediatrics, 56, 154.

Edelmann, C. M., Jr., and Spitzer, A. (1969). The maturing kidney. Fournal of Pediatrics, 75, 509.

Fomon, S. J. (1967). Infant Nutrition, p. 139. Saunders, Philadelphia and London.

Goldman, H. I., Freudenthal, R., Holland, B., and Karelitz, S. (1969). Clinical effects of two different levels of protein intake on low-birth-weight infants. Fournal of Pediatrics, 74, 881.

Goldman, H. I., Liebman, O. B., Freudenthal, R., and Reuben, R. (1971). Effects of early dietary protein intake on low-birthweight infants: evaluation at 3 years of age. fournal of Pediatrics, 78, 126.

Gordon, H. H., Harrison, H. E., and McNamara, H. (1942). The urea clearance of young premature and full term infants. fournal of Clinical Investigation, 21, 499.

Gordon, H. H., Levine, S. Z., and McNamara, H. (1947). Feeding of premature infants, a comparison of human and cow's milk. American fournal of Diseases of Children, 73, 442.

Kagan, B. M., Hess, J. H., Lundeen, E., Shafer, K., Parker, J. B., and Stigall, C. (1955). Feeding premature infants-a comparison of various milks. Pediatrics, 15, 373.

Lubchenco, L. O., Hansman, C., Dressler, M., and Boyd, E. (1963), Intrauterine growth as estimated from liveborn birth-weight data at 24 to 42 weeks of gestation. Pediatrics, 32, 793.

Macaulay, D., and Watson, M. (1967). Hypernatraemia in infants as a cause of brain damage. Archives of Disease in Childhood, 42, 485 .

McCance, R. A., Naylor, N. J. B., and Widdowson, E. M. (1954), The response of infants to a large dose of water. Archives of Disease in Childhood, 29, 104.

Macy, I. G., and Kelly, H. J. (1961). Human milk and cow's milk in infant nutrition. In Milk; The Mammary Gland and its Secretion, Vol. II, p. 265. Ed. by S. K. Kon and A. T. Cowie. Academic Press, New York.

Omans, W. B., Barness, L. A., Rose, C. S., and Gyorgy, P. (1961), Prolonged feeding studies in premature infants. Fournal of Pediatrics, 59, 951.

Rapoport, S. (1947). Hyperosmolarity and hyperelectrolytemia in pathologic conditions of childhood. American fournal of Diseases of Children, 74, 682 .

Sinclair, J. C., Driscoll, J. M., Heird, W. C., and Winters, R. W. (1970). Supportive management of the sick neonate. Pediatric Clinics of North America, 17, 863.

Snyderman, S. E., Boyer, A., Kogut, M. D., and Holt, L. E. Jr. (1969). The protein requirement of the premature infant. I. The effect of protein intake on the retention of nitrogen. fournal of Pediatrics, 74, 872.

Snyderman, S. E., Holt, L. E., Jr., Norton, P. M., Roitman, E., and Phansalkar, S. V. (1968). The plasma aminogram. I. Influence of the level of protein intake and a comparison of whole protein and amino acid diets. Pediatric Research, 2, 131.

Valman, H. B., Brown, R. J. K., Palmer, T., Oberholzer, V. G., and Levin, B. (1971). Protein intake and plasma amino-acids of infants of low birthweight. British Medical fournal, 4, 789.

Winick, M. (1969). Food, time, and cellular growth of brain. New York State fournal of Medicine, 69, 302.

Ziegler, E. E., and Fomon, S. J. (1971). Fluid intake, renal solute load, and water balance in infancy. Fournal of Pediatrics, 78, 561.

Correspondence to Dr. D. P. Davies, Department of Child Health, The Welsh National School of Medicine, Heath Park, Cardiff CF4 4XN. 